\title{
Development of A Learners' Dictionary of Polysemous \\ JAPANESE Words AND SOME Proposals For LeARners' \\ LEXICOGRAPHY
}

\author{
Shingo IMAI* \\ University of Tsukuba \\ imai.shingo@gmail.com
}

\begin{abstract}
The dictionary series Nihongo tagigo gakushü jiten (“A Learner's Dictionary of Multi-sense Japanese Words") proposes a new approach to learners' dictionaries, based on cognitive linguistics theory and on a corpus-based approach. Each entry is presented as a semantic network which follows the patterns of semantic extensions from a word's core meaning to derived meanings. A corpus, Sketch Engine, was consulted in order to select natural and frequently used examples, which were then edited to make them understandable to learners. Illustrations are also provided in an attempt to visualise the common meaning (schema) shared by the various meanings of the word.
\end{abstract}

\section{Keywords}

Learner's dictionary; monolingual Japanese dictionaries; corpus-based dictionary; semantic network; cognitive linguistics

\section{Izvleček}

Slovarska serija Nihongo tagigo gakushū jiten ("Učni slovar večpomenskih japonskih besed") prinaša nov pristop k učnim slovarjem, ki je osnovan na teoriji kognitivnega jezikoslovja in na korpusno osnovanem pristopu. Vsako geslo je predstavljeno kot semantična mreža, ki sledi vzorcem pomenskih širitev od osrednjega k drugim pomenom, ki iz tega izvirajo. Naravni in pogosti primeri rabe so bili izbrani iz korpusa s pomočjo orodja Sketch Engine in nato prirejeni, da so razumljivi uporabnikom slovarja, ki se japonščine šele učijo. Ilustracije predstavljajo skupni pomen (shemo), ki je prisoten $\mathrm{v}$ različnih podpomenih besede.

\section{Ključne besede}

učni slovar; enojezični slovarji japonščine; korpusno osnovan slovar; semantična mreža; kognitivno jezikoslovje

* Translated by Andrej Bekeš

Acta Linguistica Asiatica, 2(3), 2012.

ISSN: 2232-3317, http://revije.ff.uni-lj.si/ala/

DOI: $10.4312 /$ ala.2.3.63-76 


\section{The present state of Japanese learner's dictionaries}

In recent years many teaching materials for learning Japanese have been published, easing the long-lasting shortage of such materials. In addition, use of teaching material available on computers and internet has also been increasing. Various types of grammar manuals, sentence pattern dictionaries, thesauri etc, both for teachers and for students are being published. Yet, among these, learners' dictionaries are conspicuously absent. On the other hand, a glance at the publishing situation for learning English suffices to see that both in and outside of Japan such dictionaries are being published incessantly. The quantitative, and as a consequence the qualitative gap between learner's dictionaries for learning Japanese and English is great.

Among dictionaries for learning English produced either in the United Kingdom or in the United States, there are Merriam-Webster's Learner's Dictionary, Cambridge Advanced Learner's Dictionary, Collins Cobuild Learner's Dictionary, and Oxford Advanced Learner's Dictionary. In these dictionaries, the vocabulary used for defining the meaning of lexical items is restricted to about 2000 words, which are in themselves sufficient to describe various meanings. Thus, if one learns the vocabulary used for meaning definitions, one is able to use these dictionaries. Compared to English dictionaries, similar Japanese learner's dictionaries are few. To the author's limited knowledge, there are no Japanese dictionaries comparable to the aforementioned English dictionaries aiming at intermediate to advanced level learners. Needless to say, learners of Japanese do use dictionaries, but the dictionaries they use are either monolingual Japanese dictionaries for Japanese native speakers, or domestically produced bilingual dictionaries. The aforementioned English learner's dictionaries are in principle monolingual dictionaries. On the other hand, the yet few dictionaries targeted at learners of Japanese as a foreign language are prevalently bilingual dictionaries with headword translations or headword definitions and translations.

Monolingual Japanese dictionaries for native speakers, so-called kokugo jiten [国 語辞典] can only be used by intermediate or advanced learners. Learners usually start to use such monolingual dictionaries at the intermediate level. It goes without saying that such dictionaries have no consideration for the needs of non-native speakers and lack the information needed by learners. No monolingual Japanese dictionary for native speakers limits the vocabulary used in definition descriptions to any prescribed set. Often, definitions and explanations are more difficult to understand than the headwords they are meant to describe. Monolingual kokugo dictionaries often include also encyclopedic entries, which call for accurate encyclopedic information in their description, resulting in entries which are often difficult to understand. Learners of Japanese are more interested in the meaning and usage of individual words rather than in encyclopedic information, but such information on usage tends to be lacking in kokugo dictionaries. For example, information about the use of cases (postpositions) is not provided. Even though there are examples of use, they lack collocational information. "Shinmeikai kokugo jiten" is one of the few kokugo dictionaries which provide such kind of information, but since it is meant to be used by native speakers, 
important information needed by learners of Japanese is still insufficient. Advanced learners of Japanese do not often make grammatical mistakes any more but there is often a sense of incongruity lingering around their speech and writing. Many times the reason for this is the unnaturalness of collocations.

On the other hand, bilingual dictionaries or taiyaku jiten [対訳辞典], unlike monolingual kokugo dictionaries, are accessible also to beginners. Unfortunately, most bilingual dictionaries are basically made with Japanese native speakers in mind. Therefore, all the descriptions are made to suite the native speaker and lack the information relevant to learners. There are also bilingual dictionaries published outside Japan. Such dictionaries are made to suit the speakers of a particular language, but even such dictionaries are often based on bilingual dictionaries intended for Japanese native speakers. Therefore, for the same reason as bilingual dictionaries published in Japan, they lack the information relevant to learners of Japanese.

\section{The solutions suggested by the present dictionary}

The dictionary series Nihongo tagigo gakushū jiten [日本語多義語学習辞典], to which the present author contributed the volume on adjectives and adverbs, proposes a solution based on cognitive linguistics theory that has already been employed in some English-Japanese dictionaries, namely, a synchronic description of the meaning of basic words, which are important for learners in the form of a semantic network which follows the patterns of semantic expansion from core meanings (basic meanings) to derived meanings.

In the present dictionary series, the authors did not limit the vocabulary used in definitions to any particular set. The share of verbal information in the dictionary being smaller than in other comparable dictionaries due to the limited number of headwords (only basic words) and to the ample use of illustrations, the authors consider that limiting the defining vocabulary would not have any major effect. Instead of limiting the defining vocabulary, translations of entries into 3 languages were added as a complement to the explanations in Japanese.

By introducing the cognitive linguistics point of view, the meanings of entry items were presented as derivation networks stemming from the core meaning. Therefore the order of presenting different lexical meanings is not diachronous. As far as it is possible, it presents the cognitively central (and not necessarily the most frequent) word meaning first, followed by the various meanings derived from it, all in order to facilitate the understanding of these derivational paths. Thus senseless enumeration of unconnected entry meanings can be avoided and the organic connection between different meanings can be felt more easily, contributing to a better understanding and retention of the entry's meaning.

In addition, by consistently using examples of actual use, adapted to the level of second language learners, the dictionary is conceived so as to contribute to the 
learners' deeper understanding of each entry word, and, by supporting sentence patterns offered in textbooks with such examples, to foster a more natural use of Japanese. Examples are based on corpora, and a lot of care was given to selecting and editing natural, frequent examples. Nonetheless, the approach is not corpus-driven but corpus-based. While corpora were being used for consultation, examples were edited to be readable and learner-friendly.

\section{Intended users of the present dictionary}

While the vocabulary of the present dictionary centers on basic words which appear in textbooks for beginners, these words are actually polysemic and it is only their basic meaning that is usually introduced to beginners. Other, derived meanings not treated at the beginners' level are either introduced at the intermediate or some higher level, or, as is often the case, not treated explicitly at all in textbooks. The characteristic of this dictionary are not the descriptions of core meanings as such but how such core meanings are expanded into derived meanings. Therefore, the intended users of the present dictionary are not beginners but learners at intermediate or higher levels as well as their teachers, both native and non-native speakers. For teachers who are native speakers, derived meanings are self-evident, and they admittedly can grasp their relation to the core meaning intuitively. Yet, when teaching, it is necessary to present and explain such relations in a systematic way, and this is where the present dictionary can be of help. Further, for teachers who are not native speakers, this dictionary includes ample information such as spread of polysemy, explanations of these meanings, examples and other relevant information which can be of help to them when systematizing their own knowledge.

\section{Structure and content}

\subsection{Selection of entries}

The dictionary was complied by selecting those words in modern Japanese that are highly polysemic and therefore difficult for learners to master, and by showing word meaning networks centered on the core meanings of these basic words, in order to facilitate correct understanding and use of each word by both learners and teachers of Japanese as a second language.

The present dictionary series consists of three parts, each a separate volume, i.e., Nouns (121 headwords), Adjectives and Adverbs (84 headwords), and Verbs (104 headwords). Highly polysemous modern Japanese words were chosen as headwords. By "basic words" here the authors mean essentially words belonging to level 4 or level 3 of the former Japanese Language Proficiency Test and among them particularly those with pronounced polysemy. Further, it has to be said that words learned at the 
beginning level are most often polysemous. In such cases, it is usually the core meaning which is introduced at the beginners' level, while the derived meanings are not taught at this level. Indeed, if derived meanings are used at the intermediate or higher level at all, such words are usually treated as known words, and until now derived meanings were not taught in a systematic way. Usually what happened were occasional haphazard explanations of their meaning in some reading materials. Because of this, in spite of such words being taught at the beginners' level, it was only natural that learners experienced difficulties in learning their meanings as a complete system. Even worse, it is quite possible in such circumstances that some derived meanings that are quite distant from core meanings are not perceived as such at all.

As can be seen from the above, because of the detailed explanation of polysemous basic words, the increase in the number of pages for each word resulted in a relatively limited number of entries as compared to other dictionaries. Yet if we consider that the words appearing at intermediate and higher levels tend to be less polysemous, the number of entries is not too small for the goal of the present dictionary, which is to support learning of polysemous words, , since it covers a range of vocabulary which is conductive to reaching the expected learning targets to a considerable degree. Explanation notes are quoted below to exemplify the contents and construction of the dictionary.

\subsection{Structure of the entries}

As can be seen in Figure 1, each entry begins with the headword (1), its difficulty level (2), the kanji (Chinese characters) used for the headword, where the character in boldface is the one that expresses its most basic meaning, while characters capped with a dot are characters which are not in the official list prescribed for regular use (Jōyō kanji). This is followed by readings (3) of the boldface characters, listed in katakana for on-yomi (Chinese loanwords) and in hiragana for kun-yomi (domestic words). Examples are given in parentheses. When the entry is a kun-yomi word, it is listed here again, along with an example. This information is followed by a network diagram (4), where arrows show how each meaning derives from the core meaning. The actual derivations are more complicated than indicated, but have been simplified where possible in keeping with the dictionary's design as a learners' dictionary. The core meaning, marked with a 0 , is the meaning in modern usage that is considered the central meaning from which other meanings derive. Primary derivatives, marked with numeral $(1,2,3$ etc.) are major meanings that derive from the core meaning 0 . Secondary derivatives are marked with letters of the alphabet, as in 0a, 1a, 1b, 1c, etc. They are extended meanings that stem from the core meaning or the primary derivatives. Since they represent comparatively slight differences in meaning that do not qualify as stand-alone derivatives, they are subordinated to $0,1,2,3$, etc. 


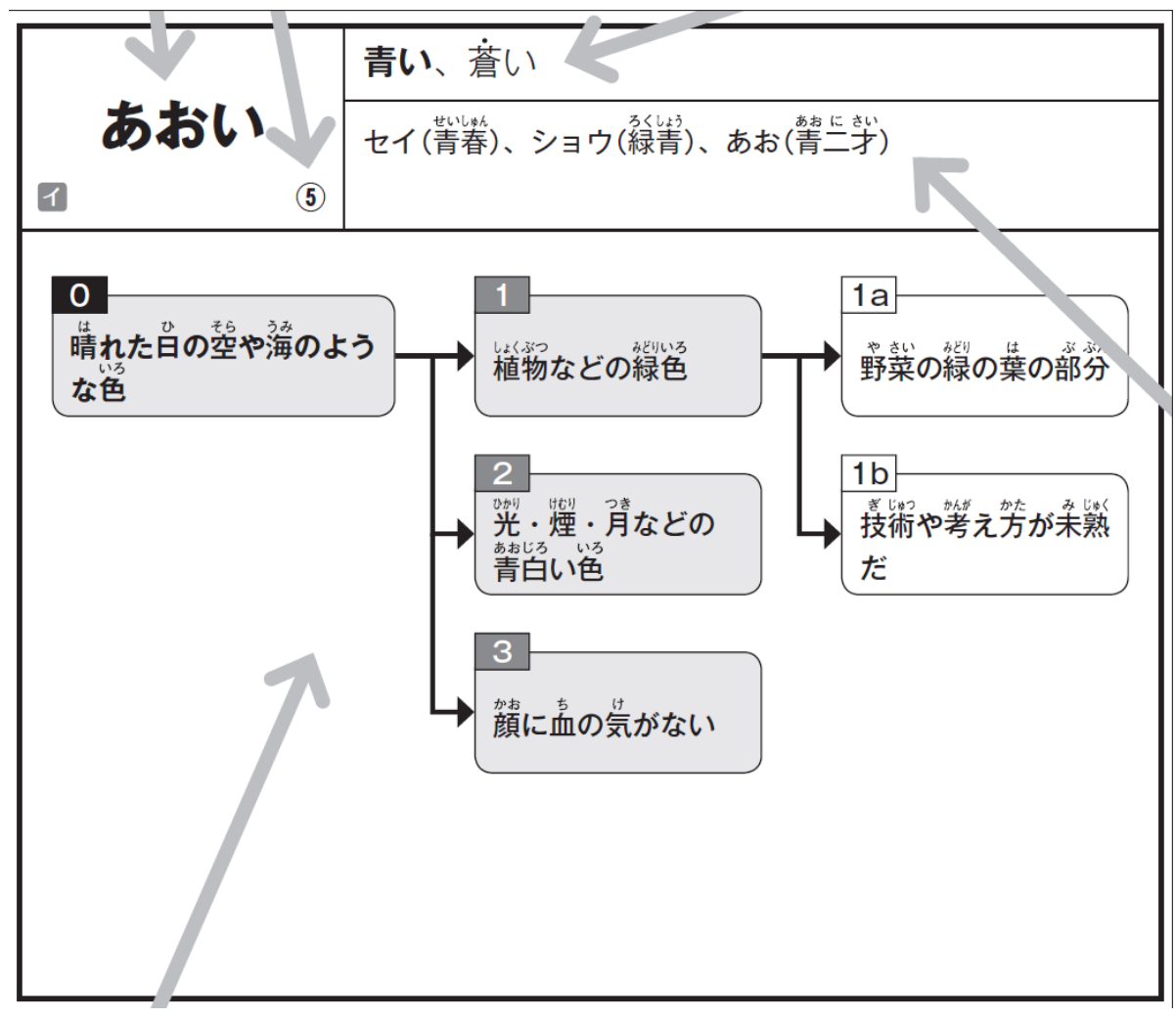

Figure 1: Structure of the headword entry

Each meaning presented in the boxes in the network diagram is then explained, translated, exemplified and illustrated as can be seen in Figure 2. The explanation (1) is given in Japanese with furigana on all Chinese characters and followed by a translation into English, Korean and Chinese. This is followed by a line (2) which describes how the meaning derives from the core meaning or the primary derivative. Example sentences (3) are provided for each meaning presented, followed by compounds, idioms, and other related expressions (4). Finally, an illustration (5) is provided to clarify the meaning. For most entries, the first example sentence is used as the basis for the illustration. These illustrations can also be used as a quick guide to the common meaning (schema) shared by the various meanings of the entry. 


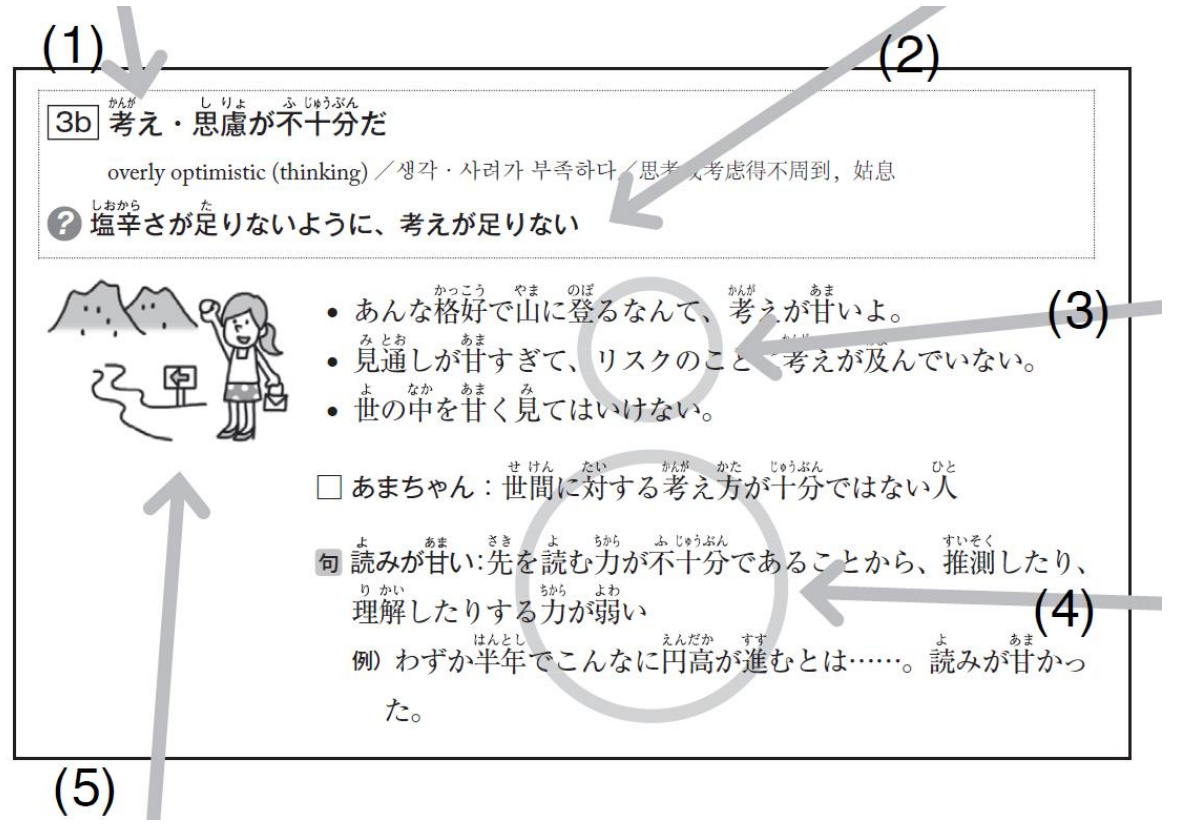

Figure 2: Meaning description with translations, illustration, examples and related expressions

When illustrations contain multiple elements, such as contrasts, the element that depicts the target meaning is generally placed on the right and/or rendered in darker shading, as can be seen in Figure 3, where the illustration conveys the target meaning "large/big (size, area)".

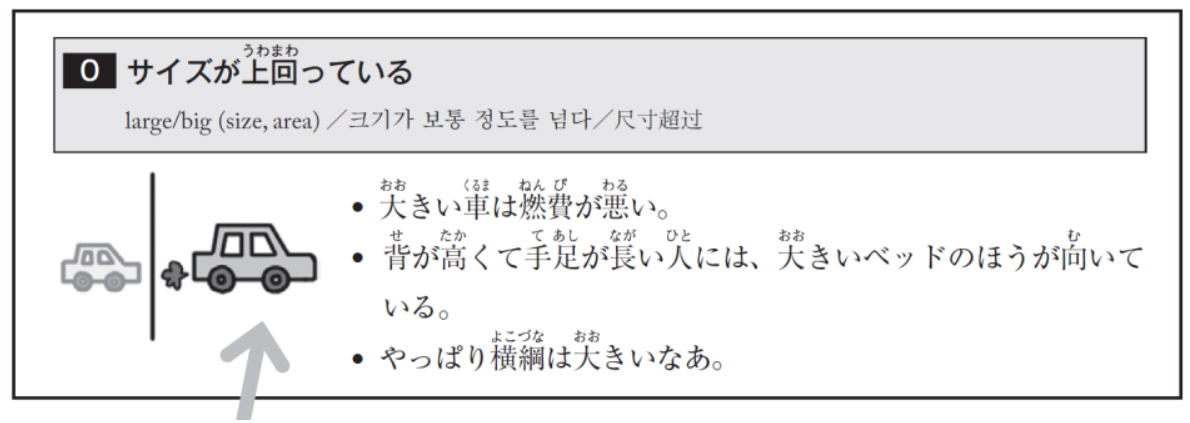

Figure 3: Illustration with multiple elements

As can be seen in Figure 4, other related expressions, such as extra compound words, idioms, transmuted words, etc. that were not covered in the meaning descriptions are enclosed in boxes marked kanrengoku [関連語句]. 


\section{関連語句}

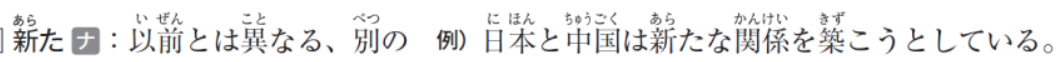

Figure 4: Box with related expressions

Distinctions in usage and other pointers on usage of the entry are given at the bottom of each entry, marked as yōhō nōto [用法ノート], as in Figure 5.

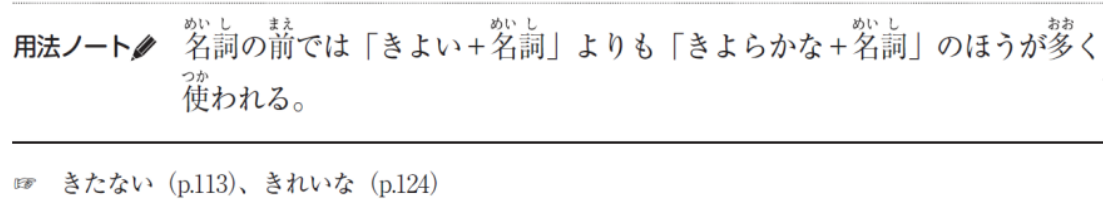

Figure 5: Usage notes and cross-references

Some entries are followed by culture notes, which provide background information on how the entry is used in the context of Japanese culture, as can be seen in Figure 6.

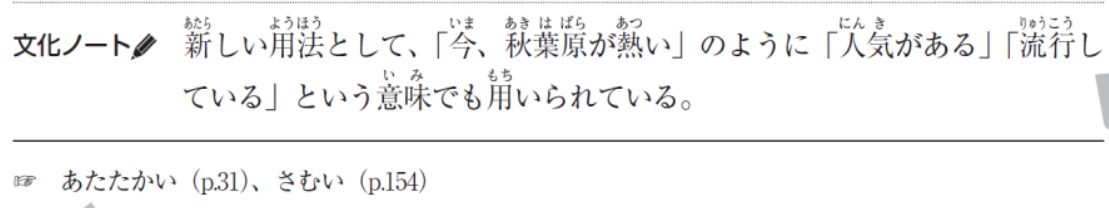

Figure 6: Culture notes and cross-references

At the bottom of each entry, there are cross-references to other entries that can be of reference, such as synonyms, antonyms, etc., which are listed with their page number, as can be seen in Figures 5 and 6.

In cases where an entry has a list of multiple Chinese characters (e.g., atsui - あつ い: 熱い暑い), users can refer to the example sentences to gain an understanding of the distinctions in usage between those characters. Particularly important distinctions are explained in the supplementary information sections marked with asterisks. 
Intuitive symbols are used to indicate various parts of the entries: $\square$ for compound words, 句 for idioms and proverbs, * for supplementary information, $\Leftrightarrow$ for antonyms, for cross-references, / for words that can be used in the same pattern (e.g. 目頭を熱

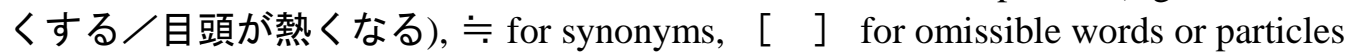
(e.g. 幸 [が] 薄い), while the parts of speech used in compound words and other related expressions are marked by symbols containing the name of the part of speech in Japanese, as can be seen in Figure 7.

\begin{tabular}{|c|c|}
\hline 名 & Noun \\
\hline 1 & $I$-adjective \\
\hline ナ & $N a$-adjective \\
\hline 副 & Adverb \\
\hline 体 & Adnominal \\
\hline スル & Suru-verb \\
\hline 動 I & $U$-verb (Group I verb) \\
\hline 動 II & $R u$-verb(Group II verb) \\
\hline 動正 & Irregular verb (Group III verb) \\
\hline
\end{tabular}

Figure 7: Symbols for parts of speech

\subsection{Additional comments on the explanation notes}

In this section, some additional explanations will be provided concerning items not appearing in the final version of the dictionary. Network diagrams show extensions of meaning, i.e., derivatives, based on metaphor (semantic extension based on similarity, e.g., ki ga omoi "depressed, heavy hearted", literally "with heavy spirit", when one's feelings are perceived heavy as a heavy object); metonymy (semantic extension based on contiguity, association, or proximity, e.g. atatakai iro "a warm color", where the property (warmth) of fire is expressed by its colour; synecdoche (extension of meaning based on subsumption or part-whole relation, e.g., hana "flower" standing for sakura "cherry blossom", where sakura is a kind of flower). While this analysis has been carried out during the process of writing, it is not mentioned in the completed version of the dictionary. The reason is that an explicit analysis was necessary during the preparation stage of the dictionary, while this type of information was deemed not to be necessarily easy to understand or relevant for the user. In meaning descriptions, under "relationship with superior meaning", the wording -yoo ni "like ..." hints at an extension based on metaphor. Also, it has to be said that derivatives should be arranged in fact "radially" and not "linearly", though for the reason of more expedient layout, they are represented "linearly". Further, the hierarchy was limited to only three levels, 
also because of layout expedience, even though there should be cases with deeper reaching hierarchies. The representation is thus simplified because of layout expedience, but at the same time also more understandable to the learner than theoretically perfectly accurate but visually complex examples. The way derivatives are divided and ordered is a particular characteristic of this dictionary, which sets it apart from other dictionaries. The division and ordering are conceived so as to help the learner intuitively grasp the connections among extensions of meaning, this being the foremost characteristics of this dictionary as a learners' dictionary.

The authors tried to describe the meanings and relationships with superior meanings in as simple Japanese words and as concisely as possible, and to further enhance the understanding by adding translations in three languages.

Example sentences are ordered so that the most prototypical examples, those with meanings and uses that are most easy to understand, come first. For the selection of examples, corpora were consulted in order to make them as natural as possible and to show relevant collocations wherever possible.

A word about illustrations. Authors strived to maintain shared characteristics between illustrations, and also for shared schemata to be discernible by comparing related illustrations, thus enabling the learner to grasp the meaning extension relationships in an intuitive way. This effort was most successful with verbs. On the other hand, adjectives and adverbs were difficult to render this way. The reason for this is that the meaning of adjectives and adverbs cannot be understood without including also the meaning of the modified part, i.e., their meaning depends very much on the modified part. Because of this, illustrations of meaning must in such cases also include the modified part, and furthermore, the modified part (which could normally be expressed by a noun) tends to become more central than the adjective/adverb itself. Consequently, illustrations change along with their modified part, thus loose the shared aspects of the core meaning and meanings of derivatives. Because of this, in the case of adjectives and adverbs, illustrations should be understood as mere "illustrations" to help with understanding of the word meaning, rather than what is in cognitive linguistics called an "image schema".

\section{Conclusion - suggestions for future learners' dictionaries}

To conclude, based on the compilation of the present dictionary, we wish to express some thoughts regarding the shape of future learners' dictionaries, hoping that they will be of help for the compilation of such dictionaries in the future.

Firstly, the necessity of corpora. There are two types of corpora useful for compiling learners' dictionaries. One type are large scale corpora representing the usage of Japanese. There are several smaller corpora of Japanese, but only two of the 
size that can be directly useful for compiling dictionaries. The first one is BCCWJ (Balanced Corpus of Contemporary Written Japanese) ${ }^{1}$, compiled by the National Institute for Japanese Language and Linguistics (Maekawa, 2012), and the second one is the corpus JpWaC included in the Sketch Engine ${ }^{2}$ (Srdanović-Erjavec, Erjavec \& Kilgarriff, 2008). BCCWJ contains one hundred million words, with attention paid to balanced sampling. As such it is one of the largest corpora in Japan, yet it is said that for compiling English dictionaries, a one billion word corpus is necessary (Akasegawa p.c.). Compared to such size, BCCWJ still suffers from size limitation, and while its sampled data are balanced, frequencies of extracted data and collocations are still inadequate. On the other hand, the Japanese language corpus within Sketch Engine comprises 5 hundred million words, and is thus larger than BCCWJ. The problem is that it consists of data automatically collected from the web, resulting in sampled data being rather slanted. Further, there are cases of special collocations stemming all from the same URL, which means that they were produced by the same person. Because of this, some caution in using the corpus is necessary. When the present dictionary was being compiled, BCCWJ was not yet available, therefore, the Sketch Engine JpWaC had to be consulted. While Sketch Engine proved to be useful for compiling example sentences, it was inadequate as far as collocations are concerned. Ideally, a corpus for the compilation of dictionaries should be balanced, and at the same time large scale. At present the authors are compiling a one billion word corpus, by collecting data automatically from the web, while striving to make it balanced. By making the corpus freely accessible to the general public, the authors hope to contribute to the compilation of future dictionaries.

Moreover, rather than compiling dictionaries relying entirely on corpora (Corpus Driven approach), an approach based on consulting corpora (Corpus Based) seems to be preferable. For example, using examples directly from the corpora is generally inadequate because it is difficult to understand such examples without access to the social and cultural schema and the immediate textual context in which they were produced. Also, since such raw examples often contain "noise", they may not always be of help to the learner. In order for the examples not to be arbitrary or unnatural, it makes sense on the other hand to consult corpora as much as possible. Yet this does not mean that with a good corpus the compilers' work is already done. On the contrary, the task of how to select good examples, how to process them, how to extract and organize relevant information from such examples, are all an important job to be done by compilers who are intimately knowledgeable about that particular language. It is difficult to expect a dictionary to be good without such efforts by its compilers.

Another type of corpora are learner corpora. Such corpora are also recently being compiled in various places, yet at present there is no such corpus with sufficient information for the compilation of dictionaries. Learners' corpora, containing much

\footnotetext{
${ }^{1}$ http://nlb.ninjal.ac.jp/

${ }^{2}$ http://ww.sketchengine.co.uk/
} 
inappropriate and mistaken usage, are difficult to tag automatically. Because they require manual tagging, the automatic compilation of such corpora is extremely difficult to realize. Our wish is that in the not so far future, with advances in automatic processing technology, the compilation of large scale learner corpora will also be easier to achieve.

The second important point regarding the future compilation of dictionaries is to produce them in digital form. As has already been mentioned in this paper, paper media impose a limitation on the available number of pages, therefore the realization of an ideally conceived dictionary is not always possible. Further, by increasing the number of entries, and by making the description more detailed, the size of the dictionary increases, making it more costly. The thicker the dictionary is, the more inconvenient it gets for the user. All these problems can be solved in one breath by making the dictionary in digital form. Limitations on the quantity of data, problems of portability etc. all disappear. With ample search functions provided, searching in such dictionary is considerably faster and more efficient than in paper dictionaries. Also, sound and images, movie clips etc., items that are impossible to include in a paper dictionary, can be easily added. Dictionaries from now on should be digital from the beginning, not like present digitalized dictionaries, based on paper editions. Indeed, in language classrooms paper dictionaries are no longer to be seen, learners are using dedicated electronic dictionaries, mobile phones and smart phones instead. Yet, at least as far as Japanese is concerned, many of such dictionaries are often nothing more than simplified digitalized versions of paper dictionaries in which much of the information that is traditionally included in dictionaries has been omitted. Further, as has been already mentioned before, such digitalized dictionaries are not primarily learners' dictionaries but monolingual kokugo Japanese dictionaries, English-Japanese bilingual dictionaries and such. Thus, while at present the access to digitalized dictionaries has become much more convenient, it is a matter of high concern that the quality of dictionaries used by learners is getting worse. What we hope for is a dictionary specifically for learners which would surpass the present paper dictionaries.

\section{References}

Imai, S. [今井 新悟] (2010). Nihongo gakushū jisho kaihatsu no kadai to yōken ni tsuite [日本 語学習辞書開発の課題と要件について] (“On the tasks and conditions for developing Japanese learners' dictionaries”), Yamaguchi kokugo kokubun [山口国語国文], 33, 86-96.

Imai, S. [今井 新悟] (2010). Risō no nihongo gakushūsha jisho o mezashite [理想の日本語学 習者辞書を目指して] (“Towards the ideal dictionary for learners of Japanese”), Nihongo gakushū jisho no kaihatsu to nihongo kenkyū yokōshū [日本語学習辞書の開発と日本語 研究予稿集] (“Japanese Linguistics and the Development of Japanese Learner's Dictionaries - Proceedings”), 1-10. Tsukuba: Tsukuba University [筑波大学]. 
Maekawa, K. [前川 喜久雄] (2012). Gendai kakikotoba kinkou koopasu (BCCWJ) no kouchiku to KOTONOHA keikaku no ayumi [現代書き言葉均衡コーパス（BCCWJ） の構築とコトノハ計画の歩み] - The construction of "the Balanced Corpus of Contemporary Written Japanese (BCCWJ)" and the progress of the KOTONOHA plan. Nihongengogakkai dai 144 kai taikai yokoushuu [日本言語学会第 144 回大会予稿集 "Proceedings of the 144th meeting of the Linguistic Society of Japan"]), 352-357.

Moriyama, S. [森山 新], Arakawa, Y. [荒川 洋平], \& Imai, S. [今井 新悟] (2009). Ninchi gengogakuteki shiten kara no nihongo gakushū jiten o kangaeru [認知言語学的視点から の日本語学習辞典を考える] (“Reflections on learners' dictionaries of Japanese from a cognitive linguistic perspective"), Paper presented at JSAA-ICJLE (Japanese Studies Association of Australia - International Conference on Japanese Language Education) Sydney, Australia: University of New South Wales.

Pardeshi, P., \& National Institute for Japanese Language and Linguistics [国立国語研究所] (2006-2009). Nihongo gakushūshayō kihondōshi yōhō handobukku no sakusei [日本語学 習者用基本動詞用法ハンドブックの作成] (“Construction of a Handbook of Basic Verbs for Learners of Japanese”). Retrieved from http://www.ninjal.ac.jp/research/project/b/youhoujiten/

Srdanović-Erjavec, I., Erjavec, T., \& Kilgarriff, A. (2008). A web corpus and word sketches for Japanese. Journal of Natural Language Processing - Shizen gengo shori [自然言語処理], 15 (2), 137-159.

\section{Dictionaries}

Arakawa, Y. [荒川 洋平] (2011). Nihongo tagigo gakushū jiten Meishi hen [日本語多義語学 習辞典 名詞編] (“A Learner's Dictionary of Multi-sense Japanese Words: Nouns”), Tokyo: ALC.

Cambridge University Press (2008). Cambridge Advanced Learner's Dictionary. Third Edition. Cambridge: Cambridge University Press.

Hornby, A.S., Cowie, A.P., \& Gimson, A.C. (1973). Oxford Advanced Learner's Dictionary of Current English. Third Edition. Oxford: Oxford University Press.

Imai, S. [今井 新悟] (2011). Nihongo tagigo gakushū jiten Keiyōshi - fukushi hen [ 日本語多 義語学習辞典 形容詞 · 副詞編] (“A Learner’s Dictionary of Multi-sense Japanese Words: Adjectives, Adverbs”), Tokyo: ALC.

Moriyama, S. [森山 新] (2012). Nihongo tagigo gakushū jiten Dōshi hen [日本語多義語学習 辞典 動詞編] (“A Learner's Dictionary of Multi-sense Japanese Words: Verbs”), Tokyo: ALC.

Perrault. S.J. (ed.) (2008). Merriam-Webster's Advanced Learner's English Dictionary. Springfield, MA: Merriam-Webster.

Sinclair, J. (ed.) (1987). Collins Cobuild English Language Dictionary. London \& Glasgow: Collins.

Yamada, T. [山田 忠雄], Shibata, T. [柴田 武], Sakai, K. [酒井 憲二], Kuramochi, Y. [倉持 保 男], Yamada, A. [山田 明雄], Uwano, Z. [上野善道], Ijima, M. [井島 正博], Sasahara, H. [笹原 宏之] (eds.) (2012). Shinmeikai kokugo jiten dai 7han [新明解国語辞典第 7 版]. Tokyo: Sanseido [三省堂]. 
